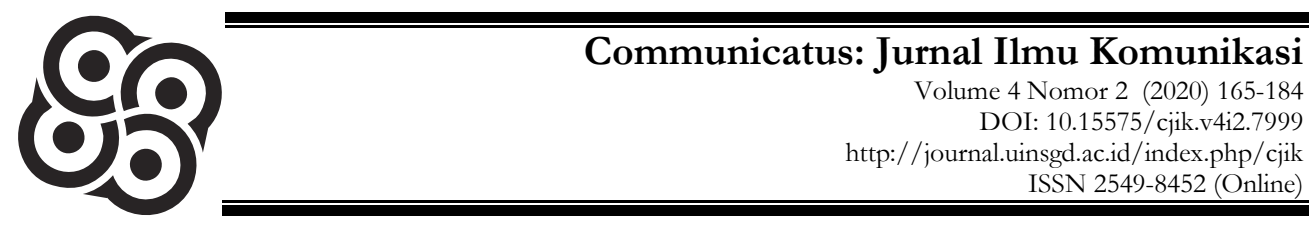

\title{
Pemahaman Dampak Game Online pada Anak-Anak Nelayan di Kota Makassar
}

\author{
Arianto ${ }^{1 *} \&$ Tuti Bahfiarti ${ }^{2}$ \\ 1,2 Universitas Hasanuddin Makassar \\ *email.arianto@unbas.ac.id
}

\begin{abstract}
This study aims to categorize the understanding of fishermen's children on the use of online games and the barriers to understanding the impact of online games on fisher children in Makassar City. This research uses a qualitative approach referring to case studies. Data were collected through non-participant observation and in-depth interviews with children aged 7-12 years selected by purposive sampling. The results showed that the understanding of fishermen's children's impact on online games has three categories: high understanding categories, characteristics of low duration and frequency, and increased interactivity playing with peers. In moderate understanding, children tend to share their time playing online games and learning with minimal time duration and frequency. In the low comprehension category, the characteristics of very intensive children have a very high duration and frequency of playing online games. The level of interactivity with peers is low. Second, the obstacles are the inadequate understanding of online games' impact on fishing communities due to parents' lack of supervision and assistance when using smartphones. Online games have the potential to lead to online game addiction and less focus on school learning, and potentially cost money in internet cafes
\end{abstract}

Keywords : Online Games; Fisherman's Children; Makassar City.

\section{ABSTRAK}

Penelitian ini bertujuan untuk mengkategorisasi pemahaman anak-anak nelayan pada penggunaan game online dan hambatan-hambatan pemahaman dampak game online pada anak-anak Nelayan di Kota Makassar. Penelitian ini menggunakan pendekatan kualitatif mengacu pada studi kasus. Pengumpulan data dilakukan melalui observasi non partisipan, dan wawancara mendalam. Hasil penelitian menunjukan bahwa, pemahaman anak-anak nelayan terhadap dampak game online memiliki tiga kategori, kategori pemahaman tinggi, karakteristiknya durasi dan frekuensi rendah, interaktifitas tinggi bermain dengan teman sebaya. Kategori pemahaman sedang, anak cenderung membagi waktu bermain game online dan belajar dengan durasi dan frekuensi waktu minim, dan kategori pemahaman rendah, karakteristiknya anak sangat intensif memiliki durasi dan frekuensi bermain game online sangat tinggi, tingkat interaktifitas dengan teman sebaya rendah. Kedua, Hambatan-hambatan rendahnya pemahaman dampak game online di lingkungan masyarakat nelayan, akibat kurangnya pengawasan dan pendampingan orang tua saat menggunakan Smartphone. Game online berpotensi menimbulkan kecanduan game online dan kurang fokus pada pembelajaran sekolah, dan berpotensi menghabiskan biaya di warung internet.

Kata kunci : Game Online, Anak-Anak Nelayan, Kota Makassar

Diterima: Juni 2020. Disetujui: Oktober 2020. Dipublikasikan: Desember 2020 


\section{PENDAHULUAN}

Perkembangan teknologi telah memudahkan masyarakat Indonesia mengakses media komunikasi tanpa ruang dan waktu. Kebermanfaatan teknologi internet menyebabkan akses informasi dan kebutuhan manusia lebih efisien. Namun. Dampak negatif teknologi, seperti media sosial dan game online berpotensi terdampak pada keseluruhan populasi penduduk Indonesia 269 juta jiwa atau 3, 49\% keseluruhan penduduk di dunia (Waldometers, 2019). Sejak tahun 2017 terdapat 50 persen atau 143 juta orang telah menikmati jaringan Internet. Hasil survei Asosiasi Penyelenggara Jasa Internet Indonesia (APJII) menunjukkan bahwa dominan mayoritas masyarakat perkotaan (urban) telah menggunakan fasilitas Internet sebanyak 72, 41 persen. Era kehadiran internet telah mengubah aktifitas manusia dalam berkomunikasi, ekonomi, bisnis, transportasi dan lainlain.

Pengguna Internet yang dikategorisasikan dari aspek wilayah geografis, antara lain Pulau Jawa telah memaksimalkan jaringan Internet sebanyak 57, 70 persen. Pulau-pulau lain di luar Jawa, seperti Sumatera 19,09 persen, Kalimantan 7,97 persen, Sulawesi 6,73 persen, Bali-Nusa 5,63 persen, dan Maluku-Papua 2,49 persen. Berdasarkan aspek kategori umur pemanfaatan internet dominan dilakukan oleh kaum millenial ada 49, 52 persen yang berumur 19 sampai 34 tahun. Kehadiran Internet bahkan menghadirkan dunia maya, seperti Selebgram (selebritas Instagram) dan YouTuber berperan membuat konten YouTube. Pengguna internet Indonesia berumur 35 hingga 54 tahun sekitar 29, 55 persen. Kategori usia produktif lebih cepat beradaptasi dengan perubahan lingkungan. Karegori remaja yang berumur 13 sampai 18 tahun berada pada posisi ketiga atau sebanyak 16, 68 persen. Kategori usia di atas 54 tahun yang lahir sebelum berkembangnya Internet hanya 4, 24 persen menggunakan Internet (Bohang, 2018).

Perkembangan teknologi internet juga berdampak pada masyarakat maritim, termasuk Indonesia. Kondisi ini berimplikasi pada pengurangan kesenjangan akses teknologi informasi, khususnya di daerah-daerah pedesaan untuk bebas mengakses informasi sesuai dengan kegunaan dan kebutuhannya, termasuk akses informasi untuk anak-anak nelayan di pesisir pantai Kota Makassar Provinsi Sulawesi Selatan. Manfaat kehadiran media teknologi komunikasi telah dimanfaatkan oleh anak-anak nelayan, berdasarkan hasil pengamatan bahwa ratarata anak-anak nelayan memiliki akses media mainstream, seperti televisi, radio, surat kabar, majalah dan film.

Faktor-faktor tingginya intensitas dan frekuensi anak-anak nelayan menggunakan internet disebabkan oleh dua faktor, antara lain pertama, ketersediaan warung-warung internet di sekitar domisili dan aktifitas keseharian berada di daerah perkotaan, seperti Makassar sehingga aksesibilitas Internet tergolong sangat cepat. Kedua, anak-anak nelayan juga memiliki akses internet melalui kepemilikan Smartphone. Ketiga, anak-anak nelayan yang tinggal di 
tengah-tengah perkotaan mahir mengakses aplikasi melalui Smartphone yang telah memiliki aplikasi Internet, seperti bermain game online, hiburan, pelajaran sekolah, dan media sosial (Instagram, Twitter, WhatsApp).

Tingkat akses informasi yang relatif tinggi dengan keberagaman terpaan informasi, menjadi pertimbangan untuk meneliti dan mengkaji pemahaman dampak game online pada pada anak-anak nelayan di Kota Makassar. Secara konseptual media massa merupakan hasil konstruksi yang isinya sarat akan kepentingan media yang bebas dan liberal. Pengembangan literasi media dapat mengimbangi efek media massa dan media baru dengan meningkatkan pengetahuan dan kemampuan orang tua dan anak-anak untuk meningkatkan pemahaman dan proses produksi pesan media-media mainstream.

Perkembangan era globalisasi dan teknologi informasi dan komunikasi berdampak pada semua aspek kehidupan manusia. Sistem informasi telah melalui proses perpindahan, pengumpulan, pengolahan, penyaringan, penginputan dan sosialisasi data secara digital (digital technology). Pergeseran media yang bersifat konvensional hingga inkonvensional, seperti media Online atau internet (interconnection and networking) telah membawa perubahan besar semua bidang kehidupan manusia. Media online merupakan menyajikan informasi dan pesan online yang dapat diakses melalui Internet. Media online (yber media) ini memiliki berbagai kategori, misalnya mesin pencari (search engine), portal, media sosial (social media), atau jejaring sosial (social networking), aplikasi chatting, surat elektronik (email). Lahirnya era teknologi informasi berbasis Online memberikan dampak yang positif di semua aspek kehidupan manusia, misalnya mempermudah pekerjaan efisiensi, kecepatan, ketepatan, keakuratan tanpa dibatasi jarak (space) dan waktu (time).

Namun, fenomena dikalangan kaum anak-anak dan remaja adalah maraknya permainan game online yang dapat diakses menjadi kegemaran dan permainan baru yang mengasyikkan. Data di tahun 2018 diprediksi ada sekitar 2,3 milyar pengguna Internet memanfaatkan bermain video game online dan 95 persen menyukai aplikasi game mobile (Newzoo, 2017). Selanjutnya, data dari Statista (2019b) tahun 2019 di Indonesia menunjukkan jumlah pendapatan dari mobile gaming mencapai 624 juta USD atau 8 triliun rupiah. Permainan game mobile yang sangat diminati kalangan anak-anak dan remaja di Indonesia berkisar 43 juta jiwa. Pemanfaatan Smartphone untuk bermain game mobile total pengguna 15.9 persen.

Penelitian-penelitian terdahulu di terhadap dampak game online, pertama diaplikasikan oleh negara-negara maju, seperti Amerika Serikat. Permainan game online telah berkembang dan digemari sebagai permainan populer di tahun 1990an. Berdasarkan data Entertainment Software Association (2018) menunjukkan bahwa rata-rata gamers di Amerika Serikat berumur 35 tahun. Hasil penelitian Kutner, dkk (2008) mengindikasikan bahwa terdapat kesadaran orang tua di Amerika Serikat pada video games dalam kehidupan sosial anak-anak. Data di 
Indonesia bermain game online juga menjadi kegemaran anak muda yang ditunjukkan melalui 36 persen gamers berada pada kategori umur 10-20 tahun, kemudian 47 persen gamers berumur 21-35 tahun, dan sekitar 17 persen berumur 36-50 tahun, hanya pemain di atas 50 tahun persentase nol.

Selanjutnya penelitian-penelitian dampak negatif bermain game online pada individu, seperti kecanduan internet, aktivitas perjudian, perusakan signifikan pada hubungan interpersonal, dan penurunan nilai akademik. Hasil penelitian Mueller, Mitchell, \& Peterson (2011). Menemukan bahwa 15\% individu kecanduan internet melakukan kegiatan perjudian melalui internet dan bermain game online. Hasil penelitian ini mengindikasikan bahwa individu dengan kepribadian yang memiliki kecenderungan tinggi untuk kecanduan akan lebih tertarik bermain game online. Selanjutnya penelitian Parker, dkk. (2008) menunjukkan bahwa pemain game yang memiliki kecerdasan emosional rendah lebih cenderung berpartisipasi dalam aktivitas perjudian dan bermain game. Bahkan dari aspek gender hasil penelitian Li (2007) menemukan bahwa perempuan dengan permasalahan hubungan interpersonal dan keluarga memiliki kecenderungan berpartisipasi dalam aktivitasaktivitas negatif seperti perjudian dan bermain game online. Faktor ini berdasarkan kajian Li (2007) karena akibat permasalahan di dunia nyata yang berkaitan dengan hubungan interpersonal memiliki hasrat atau keinginan akan mencari hubungan online sebagai pengganti hubungan gagal di dunia nyata. Bahkan menurut Kim, dkk. (2008), permasalahan hubungan interpersonal dapat menyebabkan individu mengalami kecanduan internet.

Secara teoritikal game online merupakan perkembangan dari hadirnya internet dalam kehidupan bermasyarakat. Pada awalnya media massa atau media mainstream sebagai penyampaian pesan secara serentak dengan khalayak yang anomin dengan fungsi, antara lain: pertama, industri media massa selalu mengalami perubahan dan perkembangannya sangat cepat. Kedua, media massa berperan sebagai kontrol dan kekuatan masyarakat. Ketiga, media massa merupakan sarana penyampaian peristiwa-peristiwa yang terjadi dalam masyarakat baik skala nasional maupun skala internasional. Keempat, media massa memili peran dalam pengembangan kebudayaan, baik seni dan simbol, maupun tata cara, mode, gaya dan norma-norma khidupan bermasyarakat. Kelima, media massa bermanfaat sebagai sumber informasi terhadap individu dan citra realitas sosial secara kolektif (McQuail, 1987).

Fungsi media massa yang sedemikian kompleks menyebabkan perlunya literasi media atau kita kenal dengan istilah melek media sebagai upaya alternatif untuk mengimbangi dampak dari isi-isi pemberitaan yang negatif. Cara atau strategi memahami isi-isi media melalui literasi media. Batasan literasi media menurut The National Leadership Conference on Media Literacy (Baran, 2004) adalah kemampuan mengakses, menganalisa, mengevaluasi, dan mengkomunikasikan pesan. Selanjutnya Baran (2004) memberikan gambaran literasi media sebagai upaya memahami sumber-sumber dan teknologi komunikasi, kode-kode, 
produksi pesan, proses seleksi, interpretasi, dan akibat pesan. Hal ini berkaitan dengan maraknya dampak negatif dari game online dalam kehidupan bermasyarakat, khususnya kategori anak-anak dan remaja.

Literasi media bertujuan memberikan pemahaman dan penyadaran pada masyarakat untuk "well informed" yang dapat menilai isi-isi media berdasarkan pengetahuan yang dimiliki (Eadie, 2009). Konsep literasi media dapat memfasilitasi khalayak memiliki kesadaran akan dampak-dampak isi media yang diproduksi secara sengaja. Pemahaman khalayak terhadap keberadaan media yang sengaja diproduksi untuk konsumsi khalayak dapat dipahami sebagai isi-isi media yang bebas dan liberal. Artinya bahwa isi media merupakan hasil konstruksi yang terpaannya berpotensi memiliki kepentingan media.

Selanjutnya, perlunya pemahaman unsur-unsur literasi media (Silverblat, 1995), antara lain: pertama, individu dan masyarakat memiliki kesadaran terhadap dampak media. Kedua, terdapat proses komunikasi massa yang harus disadari dan dimengerti. Ketiga, strategi untuk menganalisis dan mendiskusikan pesan media sangat diperlukan. Keempat, kesadaran isi media merupakan teks yang bermanfaat dalam memahami budaya dan diri. Kelima, pemahaman dan apresiasi perlu ditingkatkan pada isi media. Literasi media merupakan suatu kondisi timbulnya kesadaran pada khalayak akan bentukan dan produksi pesan media yang dikonstruksi berdasarkan kepentingan tertentu dari pemilik media. Pemahaman masyarakat akan konstruksi pesan media menyebabkan khalayak melek media, sehingga apa yang diterpakan tidak secara langsung mereka terima tetapi melalui proses pemahaman yang representatif terhadap dampak media komunikasi massa.

Sebagai tambahan pemahaman bahwa prinsip-prinsip literasi media yang dikemukakan oleh Aufderheide (1993), bahwa: pertama, semua media terkonstruksi (all media are constructions). Isi pesan media massa tidak menyajikan secara sederhana realitas kehidupan masyarakat, melainkan hasil produksi yang memiliki maksud tertentu. Kedua, media membentuk realitas (the media construct reality). Konstruksi media dengan sikap, interpretasi yang dibangun atas realitasnya sendiri. Ketiga, khalayak menegosiasikan makna dalam media (audience negotiate meaning in media). Merupakan kesadaran khalayak untuk berinteraksi dengan teksteks media. Keempat, media memiliki implikasi komersial (media have commercial implications). Media massa disebarkan secara serempak kepada individu, dan kelompok berdasarkan kriteria analisis pangsa pasar media massa. Kelima, media memiliki pesan bersifat ideologis dan nilai (media contain ideological and value messages). Pada esensinya bahwa produk media bukan hanya untuk personal, namun lebih luas pada tata cara nilai dan kehidupan masyarakat salam sistem sosial.

Konsep teori lainnya yang relevan dengan kajian ini adalah Teori Perbedaan Individu yang dikembangkan Defleur. Teori yang berfokus pada adanya perbedaan-perbedaan dalam diri individu sebagai target pesan media dapat memiliki pengaruh pada khalayak. Teori perbedaan individu menekankan bahwa perbedaan pengaruh disebabkan oleh perbedaan tingkat pendidikan, status sosial, 
pengalaman, pengetahuan dan keterampilan yang dimiliki khalayak.

Dalam konteks pemahaman isi media menyebabkan khalayak harus memiliki kemampuan, pengetahuan, kesadaran, dan keterampilan spesifik. Literasi media berdasarkan pandangan Chang \& Sup (2001) dalam Darwadi (2017) antara lain: pertama, khalayak harus memiliki kemampuan dalam mengakses, menganalisis, mengevaluasi, dan mengkomunikasikan pesan dalam National Leadership Conference on Media Literacy oleh (Aufderheide, 1993). Kedua, fungsi media bagi pengetahuan masyarakat (Paul Messaris, 1990). Ketiga, Pemahaman pada berbagai aspek, seperti kebudayaan, ekonomi, politik, dan keterbatasan teknologi, produksi, dan transmisi pesan. Keempat, proses kognitif untuk mendapatkan informasi harus berlandaskan pada pengetahuan, kesadaran, dan rasionalitas. Kelima, evaluasi secara kritis terhadap pesan-pesan yang diterima dan strategi mengkomunikasikan pesan. Selanjutnya, pemahaman pada sumber dan teknologi komunikasi, simbol, produksi pesan, seleksi, interpretasi, serta akibat yang ditimbulkan.

Literasi media memiliki indikator adalah, pertama, kemampuan pada selektifitas dan kategorisasi kebermanfaatan media. Kedua, khusus media televise memerlukan pemahaman bahwa lembaga tersebut berpotensi adanya kepentingan publik, ekonomi, dan sosial budaya. Ketiga, pemahaman bahwa radio dan televisi cenderung menampilkan realitas yang merupakan hasil rekayasa. Keempat, kemampuan bersikap dan berperilaku kritis pada terpaan radio dan televisi. Kelima, perlunya penyadaran pada khalayak sebagai konsumen media terhadap hak dan keajiban yang dimiliki. Keenam, identifikasi dampak media pada pengguna media. Ketujuh, selektifitas khalayak dalam memilih pesan media sangat dibutuhkan. Kedelapan, media dapat memenuhi kebutuhan dan pencapaian tujuan.

Selanjutnya, dalam teori perilaku pencarian informasi atau information seeking menganalisis pencarian, penghindaran, dan pemprosesan informasi sebagai akar pemikiran psikologi sosial. Asumsi utama dari perilaku pencarian informasi (Information Seeking) memiliki kecenderungan menghindari informasi yang tidak sesuai dengan 'image of reality'nya. Konsep ini berdasar pada pengalaman, tujuan, keyakinan, dan pengetahuan dari individu. Konsep diri individu sangat penting dalam memilih informasi sebagai upaya mengatur perilaku dalam mencari dan memproses informasi. Dalam teori pencarian informasi terdapat empat kritria perilaku mencari informasi, antara lain perilakuinformasi, perlaku pencarian informasi, perilaku mensearhing informasi, dan perilaku menggunakan informasi (Wilson, 2000). Selanjutnya, Wilson mengemukakan bahwa perilaku pencarian informasi merupakan hubungan pada pengirim dan saluran informasi meliputi pencarian informasi secara pasif dan aktif dalam menggunakan informasi. Contohnya, komunikasi tatap muka dengan orang lain, pasif menerima informasi, seperti menonton televisi, iklan, tanpa ada interaksi dalam mendapatkan informasi. 
Perilaku pencarian informasi (information seeking behavior) merupakan tujuan yang konsekuen untuk memenuhi kebutuhan. Dalam pencarian informasi individu melakukan interaksi melalui sistem informasi manual (seperti surat kabar atau perpustakaan), atau sistem jaringan seperti WWW (World Wide Web). Selanjutnya, pencarian level mikro dari pencari informasi yang berinteraksi dengan berbagai sistem. Semua interaksi dengan sistem, misalnya level interaksi manusia dnegan komputer, contohnya menggunakan mouse dan melakukan klik terhadap link) atau level intelektual merupakan strategi untuk mengdopsi strategi menentukan krteria yang tepat untuk memutuskan beberapa buku yang berasal dari perpustakaan dan menilai relevansi dari data yang diterima.

Perilaku manusia dalam mencari informasi melibatkan keseluruhan seluruh perilaku dalam keterlibatan informasi. Dalam pengertian perilaku informasi Manusia membutuhkan informasi sehingga berupaya untuk menganalisis pencarian dan manfaatkan informasi dari berbagai saluran, sumber, dan media informasi lain. Era cyber teknologi telah menyebabkan manusia berada pada kategori masyarakat informasi yang memiliki ketergantungan dalam mencari informasi berdasarakan keinginan yang diinginkan. Keaktifan khalayak menjadi sentral dengan lahirnya trend perkembangan teknologi. Pencarian informasi berfokus pada pengaplikasian penggunaan dan pemanfaatan game online dapat berdampak pada aspek akademik dan menurunnya nilai-nilai sosial dari anak-anak dan remaja.

Penelitian-penelitian terhadap dampak game online telah banyak dilakukan oleh para ahli dengan focus kajian berbeda-beda. Seperti kecanduan game online pada remaja berdasarkan hasil penelitian Novrialdy (2019) berdampak pada faktor kesehatan, faktor psikologis, faktor akademik, factor sosial dan faktor keuangan. Intensitas bermain game online berpengaruh pula terhadap interaksi sosial pada remaja (Maulida, Imawati, \& Umaroh, 2019). Bermain game online secara terus menerus dapat mengakibatkan kecanduan. Bahaya kecanduan game online dapat menimpa anak-anak maupun orang dewasa (Saputra, Harahap, \& Firdaus, 2020).

Dampak game online juga terjadi pada penurunan prestasi akademik, relasi sosial, dan kesehatan (Ghuman \& Griffiths, 2012). Remaja sangat rentan untuk kecanduan game online yang diistilahkan oleh Oblinger \& Oblinger (2005) adalah generasi post-millenials yang memiliki karakteristik hidup di zaman kecanggihan teknologi yang aksesibilitas dan keterjangkauan sangat mudah. Berdasarkan hasil penelitian bahwa remaja cenderung menghabiskan lebih banyak waktunya bermain game lebih dari dua jam/hari, atau lebih dari 14 jam/minggu (Rudhiati, Apriany, \& Hardianti, 2015). Hasil penelitian lainnya mengindikasikan bahwa remaja sangat banyak menghabiskan waktu bermain game yakni 55 jam dalam seminggu (Van Rooij, Schoenmakers, Vermulst, van den Eijnden, \& van de Mheen, 2011) atau rata-rata 20-25 jam yang digunakan bermain game dalam seminggu (Chou, Condron, \& Belland, 2005).

Kasus dampak game online telah dialami oleh 10 anak yang mengalami 
gangguan mental dan harus diterapi di Rumah Sakit Banyumas di tahun 2018. Berdasarkan data dari 10 anak yang diterapi terdapat 7 dari 10 anak masih duduk dibangku Sekolah Dasar dan Sekolah Menengah Pertama (Aziz, 2018). Meskipun pengaruh game online, khususnya Mobile Legends terhadap kualitas hubungan keluarga menggunakan family Satisfaction Scale (FSS) Olson. Hasil korelasional menunjukkan adanya hubungan positif yang berarti bahwa kualitas hubungan keluarga berpengaruh positif. Artinya bahwa signifikansi permainan game online kategori Mobile Legend berpengaruh pada kualitas hubungan keluarga (Lande, Arianto, \& Bahfiarti, 2019).

Berdasarkan kajian penelitian terdahulu dan kerangka teoritikal, maka fokus dalam penelitian ini adalah dampak game online di kalangan anak-anak nelayan dengan karakteristik yang berbeda dengan aspek pendidikan, tingkat ekonomi, dan sosial kemasyarakatan. Urgensi dampak game online sangat penting untuk memberikan pemahaman pada orang tua yang bekerja sebagai nelayan untuk mencari nafkah bahwa, bahaya yang ditimbulkan jika anak kecanduan game online. Pemahaman anak terhadap dampak game online diharapkan dapat meningkatkan peran keluarga dan lingkungan sekitar untuk menjaga dan mengontrol anak-anak dalam bermain game online, agar anak-anak bisa mengatur jam bermain game online, sehingga tidak mengganggu jam belajar. Spesifikasi penelitian ini adalah pemahaman anak-anak nelayan terhadap dampak game online yang memerlukan literasi dengan pelibatan stakeholder untuk memberikan sosialisasi dan kampanye komunikasi, khususnya masyarakat yang bekerja sebagai nelayan dan memiliki anak 6 sampai 12 tahun kategori Sekolah Dasar.

Penelitian ini secara spesik menggunakan pendekatan kualitatif bertujuan untuk menganalisis dan mengkategorisasi pemahaman dampak game online khususnya pada objek penelitian anak-anak nelayan yang tinggal di daerah perkotaan (urban), seperti Kota Makassar. Kegunaan penelitian ini adalah pertama, meningkatnya kesadaran dan mengembangkan solusi alternatif solusi pemahaman dampak game online pada anak-anak. Nelayan. Kedua, menumbuhkan motivasi dan kepedulian pemerintah, organisasi non-privat, Lembaga Swadaya Masyarakat, untuk mengembangkan literasi media sebagai pembelajaran alternatif untuk meningkatkan kesadaran anak nelayan untuk mengembangkan potensi pemanfaatan internet untuk hal yang positif bukan hanya bermain game online.

Pemilihan informan penelitian untuk menggunakan teknik penentuan informan menggunakan teknik purposive sampling. Menurut Patton (2002) pemilihan kasus (individu) dipilih secara sengaja berdasarkan kemampuan informan menjawab pertanyaan penelitian. Kriteria informan penelitian berdasarkan karakteristik anak berusia 7-12 tahun yang orang tuanya bertempat tinggal dan bersekolah di MI-MDIA Paotere Jalan. Sabutung Kelurahan Gusung Kecamatan Ujung Tanah Kota Makassar. Kategori anak-anak nelayan sebagai fokus dalam penelitian. 
Setelah melakukan observasi non partsipan dan wawancara mendalam pada 11 anak-anak yang bersekolah di MI-MDIA Paotere Jalan. Sabutung Kelurahan Gusung Kecamatan Ujung Tanah Kota Makassar. Selanjutnya, menganalisis menggunakan model interaktif Miles dan Huberman dalam Saldana (2014), memfokuskan pada aktivitas dalam analisis data kualitatif secara interaktif dilakukan secara berkelanjutan sampai peneliti menemukan data dan informasi yang sama atau datanya sudah jenuh. Aktivitas dalam analisis data, yaitu: klarifikasi data kepustakaan dan wawancara mendalam diklasifikasi. Tahap reduksi data merupakan cara mereduksi dan memilih data dari hasil diklasifikasi. Penyajian data) merupakan sajian data yang dapat dilakukan dalam bentuk uraian singkat, bagan, hubungan antar kategori, dan flowchart gainya. Conclusing Drawing/verification tahapan menyimpulkan data bersifat sementara, dan dapat berubah sesuai pembuktian dari data yang telah diperoleh pada tahap pengumpulan data.

\section{HASIL DAN PEMBAHASAN}

Penelitian pemahaman dampak game online, khususnya studi kasus anak-anak nelayan di Kota Makassar menggunakan metode kualitatif dengan memfokuskan pada keluasan (Breadth) dan kedalaman (depth). Pendekatan kualitatif peneliti yang mengacu pada studi kasus dengan menganalisis isu-isu secara spesifik dan mendalam berdasarkan kategori-kategori yang telah ditentukan. Berdasarkan hasil pengumpulan data lapangan yang dilakukan secara sistematis dan faktual pada anak-anak usia 7-12 tahun yang bersekolah di MI-MDIA Paotere Jalan. Sabutung Kelurahan Gusung Kecamatan Ujung Tanah Kota Makassar. Pemilihan lokasi tersebut disebabkan oleh dominan anak-anak nelayan di daerah perkotaan Kota Makassar bersekolah.

Hasil penelitian berfokus berfokus pada pemahaman anak terhadap dampak game online di MI-MDIA Paotere Jalan. Sabutung II Kelurahan Gusung Kecamatan Ujung Tanah Kota Makassar Provinsi Sulawesi Selatan. Berdasarkan hasil penelitian menunjukkan bahwa pemahaman anak merupakan komponen yang perlu mendapatkan perhatian dengan pembelajaran alternatif anak untuk memaksimalkan potensi belajar di sekolah dibandingkan dengan menghabiskan waktu bermain internet.

\section{Pemahaman Dampak Game Online Pada Anak-Anak Nelayan}

Dampak game online pada anak-anak disebabkan oleh faktor literasi media yang masih minim dalam masyarakat. Penelitian ini memberikan pemahaman pada khalayak, khususnya anak-anak agar memiliki kesadaran dampak game online secara sosial, psikologis dan ekonomi. Literasi media merupakan upaya menyadarkan masyarakat agar mampu memanfaatkan media lebih positif atau memfasilitasi khalayak media untuk berbudaya media. Berdasarkan wawancara mendalam dengan informan yang berjumlah 11 orang dengan umur rata-rata 7- 
Arianto \& Tuti Bahfiarti

12 tahun yang duduk dibangku kelas 1 sampai kelas VI, menunjukkan hasil seperti pada Tabel 1 berikut :

Tabel 1. Karakteristik Informan

\begin{tabular}{cccccc}
\hline No & Informan & $\begin{array}{c}\text { Umur } \\
\text { (Tahun) }\end{array}$ & Janis Kelamin & $\begin{array}{c}\text { Durasi } \\
\text { (Hari/Menit) }\end{array}$ & $\begin{array}{c}\text { Frekuensi } \\
\text { (Hari) }\end{array}$ \\
\hline 1 & Rahmat & 12 & Laki-Laki & 120 Menit & 2 \\
2 & Baso & 11 & Laki-Laki & 60 Menit & 1 \\
3 & Khadafi & 12 & Laki-Laki & 200 Menit & 2 \\
4 & Fadil & 8 & Laki-Laki & 120 Menit & 1 \\
5 & Husain & 9 & Laki-Laki & 240 Menit & 2 \\
6 & Abdul & 12 & Laki-Laki & 60 Menit & 1 \\
7 & Hasan & 12 & Laki-Laki & 100 Menit & 1 \\
8 & Lolo & 10 & Laki-Laki & 120 Menit & 2 \\
9 & Nuraeni & 12 & Perempuan & 60 Menit & 2 \\
10 & Annisa & 11 & Perempuan & 60 Menit & 2 \\
11 & Sinta & 11 & Perempuan & 30 Menit & 1 \\
& & & & &
\end{tabular}

Sumber : Data Primer, 2020

Berdasarkan data Tabel 1, menunjukkan bahwa informan jenis kelamin lakilaki sebanyak 8 orang dan perempuan hanya 3 orang. Perbandingan jumlah durasi 120 menit dalam satu hari paling tinggi digunakan anak dalam bermain game online. Data tersebut di atas menunjukkan bahwa anak laki-laki memiliki durasi dan frekuensi bermain game online lebih tinggi dibandingkan perempuan. Hal ini mengindikasikan bahwa daya tarik dan tingkat kecanduan bermain game online lebih dominan pada anak laki-laki dibandingkan dengan anak perempuan berdasarkan kasus anak-anak nelayan domisili dan beraktifitas di wilayah perkotaan (urban), khususnya Kota Makassar.

Hasil penelitian menemukan bahwa pemahaman anak masih minim terhadap dampak game online. Misalnya, kecanduan game online yang terlalu berlebihan, sangat berbahaya bagi anak-anak. Malas merupakan dampak negatif bermain game online karena setelah bermain game langsung tidur.

Faktor kurangnya waktu beristirahat, seperti kurang tidur, dapat menimbulkan kurangnya waktu belajar di rumah maupun di sekolah. Faktor radiasi yang ditimbulkan jika terlalu lama bermain game online dapat menyebabkan mata kurang sehat. Hasil penelitian dari Giri \& Dharmadi (2013) menjelaskan bahwa sebanyak 71 responden atau 83,5\% dari seluruh responden yang memiliki kebiasaan bermain video game memiliki penurunan ketajaman penglihatan baik pada satu mata atau kedua mata. Hal ini menunjukkan bahwa prevalensi kejadian kelainan refraksi pada mata cukup tinggi khususnya pada pemain game online. Mayoritas jenis video game yang sering dimainkan adalah game online $(51,1 \%)$, playstation $(45,6 \%)$ dan sisanya penggemar game gadget $(3,3 \%)$.

Kasus yang terjadi pada anak-anak nelayan yang kurang mendapat perhatian 
atau tanpa pengawasan dan pendampingan menyebabkan anak-anak memiliki waktu luang untuk bermain game online. Hal tersebut dapat berdampak pada timbulnya kecanduan game online bagi anak-anak.

Hasil penelitian menemukan dan mengkategorisasi bahwa pemahaman anak terhadap game online tergolong kategori rendah. Faktor penyebab, antara lain: minimnya pengawasan dan pendampingan orang tua terhadap anak pada saat bermain smartphone atau bermain internet di warung-warung internet yang tersedia di sekitar kediaman mereka. Kedua, faktor orang tua yang berprofesi sebagai nelayan tidak memiliki waktu tetap untuk fokus mengawasi aktifitas anakanak mereka. Ketiga, anak-anak nelayan umumnya memiliki pendapatan sendiri dengan menjadi buruh angkut di pelabuhan atau membantu mengangkat barangbarang pembeli yang dekat dari tempat pelelangan ikan Paotere. Keempat, anakanak yang bekerja memiliki pendapatan sendiri yang dapat digunakan untuk bermain game online. Hal ini disebabkan lingkungan pesisir yang masih kategori daerah perkotaan banyak menyediakan warung-warung Internet di lingkungannya.

Berdasarkan kategorisasi kasus menunjukkan bahwa terdapat tiga kategori pemahaman anak-anak terhadap game online, yakni pemahaman anak kategori rendah, kategori sedang, dan kategori rendah. Ciri dan karakteristik kategori rendah berdasarkan kasus terdapat 5 orang anak yang berjenis kelamin laki-laki. Cirinya adalah kecanduan game online yang memiliki durasi 120-240 menit dalam satu hari, tidak memiliki motivasi untuk belajar, kurang interaksi dengan teman sebaya karena lebih menyukai aktifitas bermain game, keaktifan membantu orang tua juga kurang karena lebih menyukai bermain internet, khususnya game online.

Kategori kedua adalah pemahaman sedang ditandai dengan durasi bermain game 60-100 menit dalam satu hari. Data menunjukkan bahwa terdapat lima orang anak dalam kategri sedang. Cirinya adalah kurang waktu yang digunakan bermain game online, motivasi belajar anak dan keaktifan membantu orang tua masih terlihat, kurangnya akses terpaan media yang berorientasi hiburan, dan tingkat interaktifitas bermain dengan teman sebaya masih sering dilakukan. Informan kategori sedang lebih dapat menyeimbangkan waktu belajar dengan waktu bermain game online.

Kategori ketiga adalah pemahaman tinggi menunjukkan durasi bermain game online hanya 30 menit dalam satu hari. Bahkan kategori tinggi menunjukkan durasi dan frekuensi waktu tidak memainkan game online. Mereka lebih cenderung senang untuk belajar bersama dibandingkan dengan bermain game online. Cirinya adalah memainkan game online dengan durasi dan frekuensi yang rendah, atau tidak memainkan game online dalam satu hari. Anak-anak nelayan kategori tinggi memiliki motivasi untuk belajar dan berinteraksi langsung dengan teman sebaya. Jika anak-anak tersebut memiliki pendapatan biasanya digunakan untuk membantu perekonomian keluarga. Kategorisasi pemahaman anak terhadap dampak game online berdasarkan kasus anak-anak nelayan di daerah perkotaan (urban) Kota Makassar, dapat terlihat pada gambar 1 berikut: 


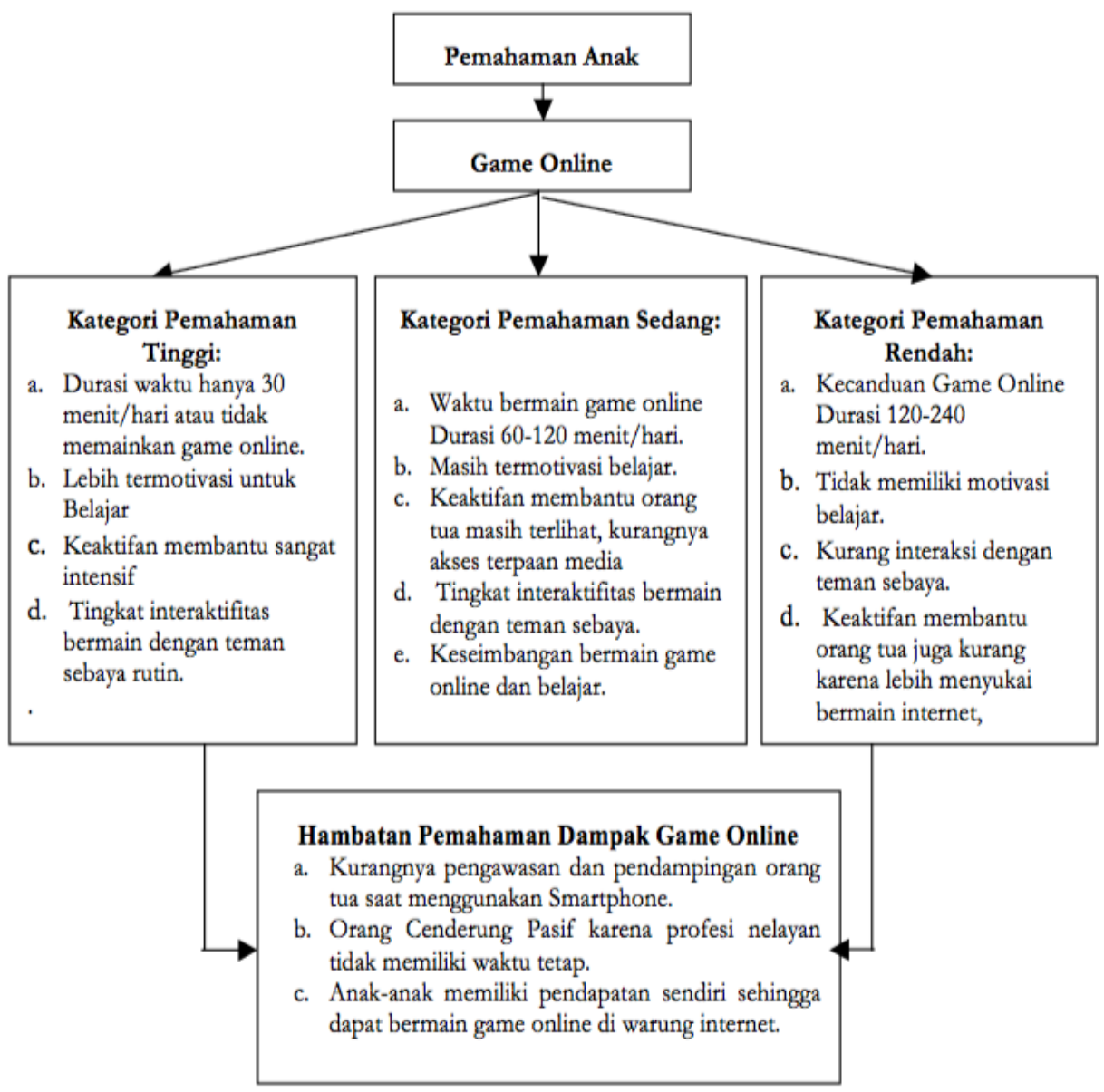

Sumber: Data Primer 202

Gambar 1. Pemahaman Dampak Game Online Anak-Anak Nelayan

Kecenderungan hasil penelitian berada pada kategori rendah, sebagai akibat kurangnya pemahaman anak dan orang tua mentransfer dampak dari game online secara berlebihan. Game online merupakan permainan yang diciptakan untuk menghibur sehingga tidak merefleksikan realitas obyektif di masyarakat. Berdasarkan hasil wawancara mendalam yang dilakukan pada anak-anak nelayan di pesisir pantai Kota Makassar ternyata mereka belum memahami pengaruh terpaan media massa, media sosial, dan permainan-permainan game online yang banyak diminati kalangan anak-anak dan remaja. Pengetahuan dan keahlian orang tua memiliki keterbatasan dalam memahami dampak dari media dan game online. Faktor keluarga inti cenderung pasif memahami isi-isi dan bahaya game online. Jadi, peran dan fungsi orang tua dalam menerapkan dan melakukan 
pendampingan, bahkan cara memilihkan dan mengatur kegiatan menonton anak, termasuk frekuensi dan durasu yang digunakan anak untu bermain game online dan menonton program acara yang tidak sesuai umur.

Hasil penelitian memiliki kecenderungan bahwa anak laki-laki lebih dominan dari aspek durasi dan frekuensi bermain game dibandingkan dengan anak perempuan. Hal ini berdasarkan konsep gender dalam masyarakat pesisir yang sangat menjaga anak perempuan mereka untuk lebih banyak dirumah membantu urusan domestik rumah tangga. Anak laki-laki juga memiliki pendapatan sendiri di pelelangan ikan sehingga memungkinkan mereka untuk bermain internet dari hasil keringat mereka sendiri. Kondisi ini dapat lebih memperburuk dampak negatif dibandingkan dengan dampak positifnya. Dampak negatif bermain game online, seperti kecanduan game yang terlalu berlebihan berbahaya bagi anak-anak. Malas merupakan dampak negatif bermain game online karena setelah bermain game anak-anak kelelahan sehingga langsung tertidur. Faktor lainnya adalah kelelahan fisik, depresi dan kerugian dari aspek ekonomi. Radiasi dari bermain game online yang terlalu sening menyebabkan mata kurang sehat. Karena itu, aktifitas anak bermain game online harus dalam pengawasan dan pendampingan orang tua.

\section{Hambatan-Hambatan Pemahaman Dampak Game Online Pada Anak- Anak Nelayan}

Hambatan-hambatan rendahnya pemahaman dampak game online di lingkungan masyarakat nelayan, akibat kurangnya pengawasan dan pendampingan orang tua saat menggunakan Smartphone. Pekerjaan sebagai nelayan menyebabkan orang tua cenderung pasif karena tidak memiliki waktu tetap untuk mengontrol anak pada saat bermain game online dan isi dari permainan tersebut. Di sisi lain anakanak nelayan memiliki pendapatan sendiri sehingga dapat bermain game online di warung internet. Pendapatan yang mereka dapatkan melalui pekerjaan mereka membantu proses jual beli, sebagai pengangkat barang bagi pembeli yang berada di sekitar pelelangan. Faktor-faktor inilah yang menjadi penghambat rendahnya pemahaman anak terhadap dampak game online. Hasil penelitian ini mengindikasikan pentingnya pelibatan keluarga inti, seperti ayah, ibu dan saudara yang dapat membantu pengawasan anak ketika bermain game online atau mengurangi aktifitas anak di warung-warung internet.

Dalam konsep Teori Perbedaan Individu atau Differences Theory of Mass Communication Effect Melvin D. Defleur memberikan kontribusi bahwa setiap individu memiliki perbedaan-perbedaan dan dampak dari terpaan pesan atau informasi yang diterima. Teori perbedaan individu menekankan bahwa perbedaan pengaruh disebabkan oleh latar belakang pendidikan, status sosial, pengalaman, pengetahuan dan keterampilan anak-anak karena sikap pasif dari orang tua berpotensi memberikan dampak negatif yang lebih tinggi dibandingkan dengan dampak positif yang diterima. Dalam teori perbedaan individual terdapat 
rangsangan-rangsangan berbeda terhadap pesan-pesan yang diterima khalayak. Hal ini menyebabkan munculnya perbedaan individual secara alamiah akibat dampak dari pesan yang diterima atau teori ini memprediksi keberagaman tanggapan khalayak.

Dampak negatif game online harus mendapat perhatian dari orang tua. Hal ini berdasarkan pandangan Bassiouni \& Hackley (2016) bahwa bermain game online berpengaruh terhadap pembentukan identitas anak-anak. Indikasi dari hasil penelitian ini bahwa pemahaman terhadap dampak gama online harud dipahami untuk membantu proses pembentukan identitas anak-anak dalam berinteraksi dengan lingkungan internal dan eksternalnya. Orang tua perlu menyadari bahwa game online bukan solusi untuk mengisi atau memanfaatkan waktu luang melainkan sumber daya kultural dalam hubungan interpersonal.

Hasil penelitian yang menghasilkan rendahnya pemahaman dampak game online berkaitan dengan ketakutan World Health Organization (WHO) akan gangguan mental yang akan diakibatkan dari kecanduan game online. Pada tahun 2013 World Health Organization (WHO) menetapkan gangguan mental atau Internet Gaming Disorder sebagai "pola perilaku gaming (digital-gaming atau video-gaming) yang dicirikan dengan terganggunya kemampuan kontrol diri sebagai akibat dari bermain game" (American Psychiatric Association, 2013). Faktor usia anak-anak sangat rentan dari dampak terpaan media yang berlebihan seperti pandangan Anderson, dkk. (2017), bahwa kelompok usia 12 - 29 tahun dominan mengalami gangguan kecanduan Internet.

Gejala kecanduan Internet merupakan gangguan-gangguan dalam kehidupan anak-anak dan remaja termasuk anak-anak nelayan yang secara intensitas kurang mendapatkan pengawasan dari orang tua. Anak-anak dan remaja sangat rentan terpengaruh dan terdampak kecanduan game online (Brand, Todhunter, \& Jervis, 2017). Hal ini mengindikasikan perlunya memperhatikan hambatan-hambatan anak dalam memahami dampak game online dan keterlibatan keluarga dalam proses pengawasan. Keterlibatan keluarga sangat penting karena remaja lebih memanfaatkan media elektronik yang tersedia untuk bermain game yang lebih menarik dibandingkan membaca buku (Gentile et al, 2017). Ketersediaan sumber informasi di lingkungan sekitar sangat berpengaruh terhadap ksukaan bermain game online. Hal ini juga termasuk dalam minat bermain game online (Blakely, Skirton, Cooper, Allum, \& Nelmes, 2010). Kecenderungan yang terjadi pada anak-anak nelayan yang dapat mencari uang sendiri mempermudah mereka untuk bermain game online di warung-warung internet tanpa pengawasan orang tua. Ruang gerak anak lebih bebas karena mermain game online di luar lingkungan keluarga.

Kecenderungan hasil penelitian pemahaman dampak game online yang telah memasuki aspek kehidupan keluarga, khususnya anak-anak 6 sampai 12 tahun cenderung rendah. Hal ini dapat berpotensi anak-anak nelayan yang menjadi fokus penelitian dapat kecanduang game online yang secara sosial, kesehatan dan 
psikologis dapat menyebabkan anak depresi. Hal ini didukung oleh hasil-hasil penelitian sebelumnya bahwa kecanduan game online pada remaja di Indonesia terdata bahwa 10,15\% remaja mengalami kecanduan game online dengan perbandingan 1 banding 10 anak terindikasi kecanduan game online (Jap, Tiatri, Jaya, \& Suteja, 2013). Artinya, 1 dari 10 remaja di Indonesia terindikasi mengalami kecanduan game online. Akibat yang ditimbulkan kecanduan game online menjadi permasalahan kompleks yang membutuhkan semua kalangan utamanya keluarga inti untuk melakukan mendampingan kepada anak saat bermain gadget. Penelitian relevan terhadap dampak game online pada remaja yang cenderung kurang tertarik melakukan aktifitas keseharian yang berinteraksi dengan teman sebayanya. Secara psikologis anak-anak remaja cenderung gelisah pada saat tidak melakukan permainan game online (Jannah, Mudjiran, \& Nirwana, 2015).

Perkembangan media baru, termasuk media sosial yang menyebabkan khalayak aktif mencari informasi berdampak pada aktifitas anak bermain game online. Bahkan hasil penelitian pengaruh media sosial sebagai media komunikasi bukan hanya kecanduan game online tetapi dampak terhadap transaksi tingkat pidana penggunaan narkotika di wilayah Sulawesi Tenggara. Kondisi perkembangan media baru, seperti media sosial memiliki sisi positif, namun ada aspek negatif yang menjadi kekhawatiran khususnya dampaknya pada anak-anak yang belum memiliki literasi. Seluruh unsur harus terlibat untuk mengantisipasi dampak media sosial, game online, seperti keluarga sebagai unit terkecil, kelompok rujukan atau teman sebaya, guru di sekolah, Lembaga profit dan non profit (pemerintah) harus berkontribusi memberikan sosialisasi dan kampanye komunikasi yang berkelanjutan sehingga anak termotivasi untuk tidak bermain game online atau mengurangi permainan game online di bawah pengawasan orang tua. Penelitian ini berkontribusi bahwa permainan game online sangat menarik dan disukai oleh anak-anak dan remaja sehingga pendampingan sangat penting dilakukan di lingkungan keluarga dan sekolah.

\section{PENUTUP}

Berdasarkan hasil penelitian dapat disimpulkan bahwa pemahaman dampak game online bagi anak-anak nelayan pesisir menunjukkan kategori rendah. Hal ini menyebabkan anak-anak kecanduan game online dengan durasi 120-240 menit/hari. Akibatnya anak-anak nelayan tidak memiliki motivasi belajar, kurang interaksi dengan teman sebaya karena lebih menyukai aktifitas bermain game, keaktifan membantu orang tua juga kurang karena lebih menyukai bermain internet, khususnya game online. Kategori sedang ditandai dengan durasi bermain game 60-100 menit/hari. Akibatnya anak-anak nelayan meminimalkan waktu bermain game online, motivasi belajar anak dan keaktifan membantu orang tua dan tingkat interaktifitas bermain dengan teman sebaya masih sering dilakukan. Kategori tinggi menunjukkan durasi bermain game online hanya 30 menit/hari 
atau durasi dan frekuensi waktu tidak memainkan game online. Akibatnya, anakanak nelayan lebih cenderung senang untuk belajar bersama dibandingkan dengan bermain game online. Kategori tinggi memainkan game online dengan durasi dan frekuensi yang rendah, atau tidak memainkan game online dalam satu hari. Anakanak nelayan kategori tinggi memiliki motivasi untuk belajar dan berinteraksi langsung dengan teman sebaya. Jika anak-anak tersebut memiliki pendapatan biasanya digunakan untuk membantu perekonomian keluarga. Faktor yang menyebabkan rendahnya pemahaman anak juga disebabkan anak-anak nelayan pesisir memiliki pendapatan untuk digunakan bermain game online yang tersebar di lingkungan tempat tinggal mereka, seperti warung-warung internet.

Hasil penelitian ini memberikan kontribusi sikap aktif orang tua sangat dibutuhkan untuk menemani anak-anak dalam mengakses informasi dan hiburan yang disukai. Untuk itu diperlukan pengawasan dan pendampingan orang tua terhadap anak pada saat bermain smartphone atau bermain internet di warungwarung internet. Faktor literasi media pada orang tua memiliki rutinitas waktu tetap untuk fokus mengawasi aktifitas anak-anak mereka. Penelitian selanjutnya, dapat lebih mengefektikan literasi media yang berfokus pada orang tua sehingga terjadi keseimbangan menerima isi pesan media yang beragam. Faktor penelitian pengawasan orang tua dari aspek komunikasi keluarga untuk meminimalisasi dampak penggunaan game online pada anak-anak.

\section{DAFTAR PUSTAKA}

American Psychiatric Association. (2013). Diagnostic and Statistical Manual of Mental Disorders (5th ed.). Arlington, VA: Author.

Aufderheide, P. (1993). Media Literacy: A Report of The National Leadership Conference on Media Literacy. Aspen: Aspen Institute.

Aziz, A. (2018). Kecanduan game online, 10 anak Banyumas alami gangguan mental. Diakses 7 September 2019, dari https://www.merdeka.com/peristiwa/ kecanduan-game-online-10-anakdibanyumas-alami-gangguanmental.html

Baran, Stanley J. (1999). Introducing to Mass Communication Media Literacy and Culture. California, California : Mayfield Publishing Company.

Bassiouni, D. H., \& Hackley, C. (2014). 'Generation Z'children's Adaptation To Digital Consumer Culture: A Critical Literature Review. Journal of Customer Behaviour, 13(2), 113-133. DOI: 10.1362/147539214X14024779483591

Blakely, G., Skirton, H., Cooper, S., Allum, P., \& Nelmes, P. (2010). Use of educational games in the health professions: A mixed-methods study of educators' perspectives in the UK. Nursing and Health Sciences, 12(1), $27-$ 32. doi: 10.1111/j.1442-2018.2009. 00479.x

Bohang, F. K. (2018). Kompas.com "Berapa Jumlah Pengguna Internet Indonesia?". $\begin{array}{llll}\text { diakses } & 5 & \text { Maret } & 2020 .\end{array}$ https://tekno.kompas.com/read/2018/02/22/16453177/berapa-jumlah- 
pengguna-internet-indonesia.

Brand, J. E., Todhunter, S., \& Jervis, J. (2017). Digital Australia 2018 (DA18). http://www.igea.net/wpcontent/uploads/2017/07/DigitalAustralia-2018DA18-Final-1.pdf

Chou, C., Condron, L., \& Belland, J. C. (2005). A review of the research on Internet addiction. Educational Psychology Review, 17(4), 363-388. doi: $10.1007 /$ s10648-005-8138-1

CNN Indonesia, (2019). WHO: Kecanduan Video Game Termasuk Penyakit Modern

Creswell, John W. (1994). Research Design: Qualitative and Quantitative Approaches. Thousand Oaks, Sage, California.

Darwadi. (2017). Media Baru Sebagai Informasi Budaya Global. Jurnal Komunikator. 9 (1) 2017. Retrived 1 Agustus 2010.

De Fleur , Melvin L. \& Sandra B.L (1982), Theories of Mass Communication, Fourth Edition, New York, Kongman Inc. p173.

Eadie, F. W. (2009). 21st Century Communication A Reference Handbook, Volume 2. Thousand Oaks. California: SAGE Publications, Inc

Gentile, D. A., Bailey, K., Bavalier, D., Brockmyer, J. F., Cash, H., Coyne, S. M.,Young, K. S. (2017). Internet gaming disorder in children and adolescents. Pediatrics, $140(2)$, S81-S85. Retrieved from $\% 3 C G 0 \% 0 A$ to

Ghuman, D., \& Griffiths, M. D. (2012). A cross-genre study of online gaming: Player demographics, motivation for play and social interactions among players. International Journal of Cyber Behavior, Psychology and Learning, 2(1), 13-29.

Giri, K.G., \& Dharmadi, M. (2013). Gambaran Ketajaman Penglihatan Berdasarkan Intensitas Bermain Game Siswa Lakilaki Sekolah Menengah Pertama di Wilayah Kerja Puskesmas Gianyar I Bulan Maret-April 2013.

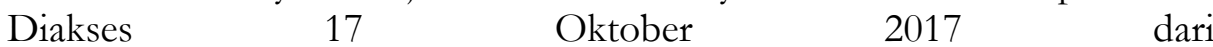
https://ojs.unud.ac.id/index.php/eum/article/view/12642/8664

Jannah, N., Mudjiran, M., \& Nirwana, H. (2015). Hubungan kecanduan game dengan motivasi belajar siswa dan implikasinya terhadap Bimbingan dan Konseling. Konselor, 4(4), 200-207. doi: 10.24036/02015446473-0-00

Jap, T., Tiatri, S., Jaya, E. S., \& Suteja, M. S. (2013). The development of Indonesian online game addiction questionnaire. Buletin Psikologi PLoS ONE, 8(4), 4-8. doi: 10.1371/ journal.pone.0061098

Kim, E., Namkoong, K., Ku, T., \& Kim, S. (2008). The Relationship Between Online Games Addiction and Aggression, Self-control, and Narcissistic Personality Traits. European Psychiatry, 23, 212-218.

Kutner, L., Olson, C., Warner, D., \& Hertzog, S. (2008). Parents' and Sons' Perspectives on Video Game Play. Journal of Adolescent Research, 23, 76-96.

Lande, J.P., Arianto \& Bahfiarti, T. Pengaruh Mobile Gaming Pada Tingkat Kepuasan Hubungan Keluarga. Kareba: Jurnal Ilmu Komunikasi, 8(2), 2019, 289-299. https://doi.org/10.31947/kareba.v8i2.8871 
Li, J. (2007). Women's Ways of Gambling and Gender-specific Research. Sociological Inquiry, 77, 626-636.

Mardiana. (2018). Pengaruh Media Sosial terhadap Tingkat Pidana Narkotika di Sulawesi Tenggara. Communicatus: Jurnal Ilmu Komunikasi. 2(2), 2018), 109122 DOI: $10.15575 /$ cjik.v2i2.3659

Maulida, A., Diana Imawati, D., \& Umaroh, S.K. (2019). Pengaruh Intensitas Bermain Game Online Terhadap Interaksi Sosial Remaja. Jurnal Motivasi, 7(1). http://ejurnal.untag-smd.ac.id/index.php/MTV/article/view/4496

McQuail, D. (1987). Mass Communication Theory (Teori Komunikasi Massa).Jakarta: Erlangga

Mitchell, K., Becker-Blease, K., \& Finkelhor, D. 2005. Inventory of Problematic Internet Experiences Encountered in Clinical Practice. Professional Psychology: Research and Practice, 36, 498-509.

Mueller, A., Mitchell, J.E., Peterson, L.A. (2011). Depression, materialism, and excessive internet use in relation to compulsive buying. Comprehensive Psychiatry, 52, 420-424

Newzoo. (2017). The Indonesian Gamer 2017. Retrieved from newzoo Website: https://newzoo.com/insights/infographics/the-indonesian-gamer-2017/

Newzoo. (2018). 2018 Global Games Market Report. Retrieved from newzoo Website:https://resources.newzoo.com/hubfs/Reports/Newzoo_2018_

Global_Games_Market_Report_Light.pdf

Newzoo. (2018a). Top 50 Countries/Markets by Smartphone Users and Penetration. https:// newzoo.com/insights/rankings/top-50-countries-bysmartphone-penetration-and-users/

Novrialdy, E., Nirwana, H., \& Ahmad, R. (2019). High school students understanding of the risks of online game addiction. Journal of Educational and Learning Studies, 2(2), 113-119.

Novrialdy. Kecanduan Game Online pada Remaja: Dampak dan Pencegahannya

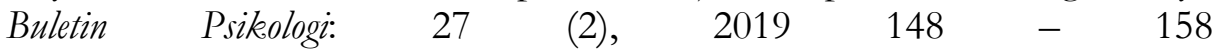
DOI:10.22146/buletinpsikologi.47402.https://jurnal.ugm.ac.id/buletinpsi kologi

Oblinger, D., \& Oblinger, J. L. (2005). Is it age or IT: First step toward understanding the net generation. In Diana Oblinger \& J. L. Oblinger (Eds.), Educating the net generation. Washington D.C.: Educause.

Parker, J., Tayler, R., Easetabrook, J., Schell, S., \& Wood, L. (2008). Problem Gambling in Adolescence: Relationships with Internet Misuse, Gaming Abuse, and Emotional Intelligence. Personality and Individual Differences, 45, 174-180.

Rochimah, Nur, T.H. (2013). Media Parenting: Panduan Memilih Media bagi Anak di Era Informasi. Yogyakarta, Mata Padi Pressindo

Rudhiati, F., Apriany, D., \& Hardianti, N. (2015). Hubungan durasi bermain video game dengan ketajaman penglihatan anak usia sekolah. Skolastik 
Keperawatan, 1(2), 12-17.

Saldana., Miles \& Huberman. (2014). Qualitative Data Analysis. America: SAGE Publications.

Saputra, D.E., Harahap, R.K., \& Firdaus, R.R. (2020). Prototipe Aplikasi Dekstop untuk Identifikasi Kecanduan Game Online. Jumal Ilmiah Komputasi, 19(1).

Silverblatt. (1995). Media Literacy: Key To Interprenting Media Massages. Publisher: Preager. USA.

Straubhaar dan LaRose. (1997). Communications Media in the Information Society. Wadsworth Publishing, United State of Amerika.

Tamburaka, Apriadi. (2013), Literasi Media, Cerdas Bermedia Khalayak Media Massa, edisi pertama, penerbit: Rajawali Pers, Jakarta.

Van Rooij, A. J., Schoenmakers, T. M., Vermulst, A. A., van den Eijnden, R. J. J. M., \& van de Mheen, D. (2011). Online video game addiction: Identification of addicted adolescent gamers. Addiction, 106(1), 205-212. doi: 10.1111/j.1360-0443.2010.03104.x

Waldometers. (2019). Jumlah Penduduk Indonesia 269 Juta Jiwa terbesar $\begin{array}{llll}\text { Keempat Dunia. } & \text { Diakses }\end{array}$ https://databoks.katadata.co.id/datapublish/2019/04/29/jumlahpenduduk-indonesia-269-juta-jiwa-terbesar-keempat-dunia

Wilson, TD. 2000. Human Information Behaviour. Information Science. Vol 3. Retrived 1 August 2000.

Yosal. (2013). Literasi Media: Apa, Mengapa, Bagaimana. Simbiosa Rekatama Media, Bandung. 